\title{
Corpus
}

\section{Brigitte Buffard-Moret (éd.) - Introduction à la stylistique. Paris : Armand Colin, 2005, 128 pages, 9 euros}

\section{Véronique Magri-Mourgues}

\section{(2) OpenEdition \\ Journals}

Édition électronique

URL : http://journals.openedition.org/corpus/541

DOI : $10.4000 /$ corpus.541

ISSN : $1765-3126$

Éditeur

Bases; corpus et langage - UMR 6039

Édition imprimée

Date de publication : 1 décembre 2006

ISSN : 1638-9808

Référence électronique

Véronique Magri-Mourgues, «Brigitte Buffard-Moret (éd.) - Introduction à la stylistique. Paris : Armand Colin, 2005, 128 pages, 9 euros », Corpus [En ligne], 5 | 2006, mis en ligne le 26 août 2007, consulté le 24 septembre 2020. URL : http://journals.openedition.org/corpus/541 ; DOI : https://doi.org/10.4000/ corpus.541

Ce document a été généré automatiquement le 24 septembre 2020

(c) Tous droits réservés 


\title{
Brigitte Buffard-Moret (éd.) - Introduction à la stylistique. Paris : Armand Colin, 2005, 128 pages, 9 euros
}

\author{
Véronique Magri-Mourgues
}

Il s'agit là de la réédition d'un ouvrage du même titre paru aux Éditions Dunod en 1998 ; deux exemples d'analyse stylistique ont été ajoutés et la bibliographie a été légèrement modifiée, tout en restant un peu ancienne. L'ouvrage propose, de manière didactique, une méthode d'analyse stylistique du texte littéraire à l'usage des étudiants du premier cycle universitaire, organisée autour de grands chapitres, comme l'organisation textuelle, l'énonciation, les procédés syntaxiques et lexicaux, les figures de rhétorique. Chacun est illustré d'exemples variés dont un commentaire est esquissé. Cet ouvrage pointe les outils d'analyse indispensables pour l'observation, le classement et l'interprétation stylistique des faits de langue, en inventoriant les connaissances de base que doit acquérir tout étudiant en lettres et en lui donnant quelques réflexes d'analyse. Les exemples d'études stylistiques se présentent comme l'application quelque peu mécanique et systématique de cet inventaire. Nul doute qu'il conviendrait d'introduire nuances et approfondissements pour qui voudrait aller plus loin. 